Page 258-266. ISBN: 978-602-6 988-75-1

Web Jurnal Online: jurnal.unmuhjember.ac.id

By: Wheny Kristianto

Investigating It Governance Validity In Higher Education Institution: An Empirical Study

\title{
INVESTIGATING IT GOVERNANCE VALIDITY IN HIGHER EDUCATION INSTITUTION: An Empirical Study
}

\author{
By: Wheny Khristianto \\ Post Graduate Program of Business Administration \\ Faculty of Administrative Science \\ University of Brawijaya, Indonesia \\ E-mail: wheny.fisip@unej.ac.id
}

\begin{abstract}
The purpose of this paper is to investigate the validity of the higher education academic staffs in IT governance studies and the future improvement for IT governance and controls. This research used a quantitative survey to identify the current state of IT governance for five higher education institutions in East Java, Indonesia. The questionnaires were distributed to post-graduate student as IT executives in their higher education institution. A total of 34 out of 40 post academic staffs completed the questionnaire, representing a response rate of 85 percent. This study found that attributes for deliver value (V2), attainment and retain people with key competencies (V6), capture knowledge to improve performance (V10), stakeholder satisfaction (V11), reach economies of scale (V17), deliver successul IT project (V19), understand business unit strategies (V20), and understand emerging technologies (V22) show no significant difference $(\mathrm{p}<0.05)$ between mean interests and performance. In addition to these, other 15 attributes show significant differences in the t-test in the negative direction. This points to the fact that actual control of IT governance in colleges is monitored less than expected. Therefore, five higher education institutions in East Java should pay more attention to the identified attributes important to balance the gap between the importance and performance of these attributes.
\end{abstract}

Keywords: IT governance, IT governance balanced scorecard, Importance-performance analysis, higher education institution 
Proceeding ICOGISS 2019

Page 258-266. ISBN: 978-602-6 988-75-1

Web Jurnal Online: jurnal.unmuhjember.ac.id

By: Wheny Kristianto

Investigating It Governance Validity In Higher Education Institution: An Empirical Study

\section{Introduction}

Good Information Technology (IT) governance will greatly support organizational activities in achieving goals that include the organization's vision and mission as it requires a consistency in business strategy and information system (IS) / IT strategy. Recently, the development of IT also masiv happening in the world of education, especially in college education. With increased pressure from globalization, changes in funding structures in higher education, and changes in supply and demand for higher education, many higher education institutions around the world seek to survive and seek competitive advantage through innovation (Brown, 2008; OECD, 2009; Gibbs and Barnett, 2014; Gaspar and Mabic, 2015). To gain competitive advantage and innovation power, higher education undertake the adoption of information technology.

Stakeholders in colleges are seeking to advantage from developing IT governance. The higher education sector is haunted by a large number of challenges including technological developments and new demands in the education sector around the world, all of which make the field of higher education an exciting field for research (Mathew, 2010). Factors influencing innovation in higher education institutions thus always represent vital areas of concern in the field of organizational studies (Meek et al., 2009). Typically, the existing literature is a common position that successful innovative practices within an organization build relationships between individual and institutional factors (Hoidn and Kärkkäinen, 2014; Zhu, 2015). Both of them are also supported by IT for developing innovation and creativity.

In particular, the use of IT Balanced Scorecard in higher education institutions in Indonesia has not been widely implemented (Prabowo, 2007). Previous studies related to IT governance in Indonesia in higher education have highlighted the important role played by IT governance using BSC (Solechan, 2015; Misbah et al., 2017; Haerani, 2017). BSC IT can play an important role in the overall program in heigher education institutions, empowering the structural ranks (Haerani, 2017), but with regard to the effectiveness of this method, higher education institutions need to organize the ICT organization and simultaneously evaluate the success of system / application development. The purpose of this study is to investigate the validity of the higher education academic staffs in IT governance studies. Our study addresses a major issue in IT governance research in higher education contexts. Secondly, this study aims to clarify the actual practice of IT governance in higher education and to determine IT governance strategy for higher education institutions in Indonesia, especially in East Java.

\section{Literature review \\ 2.1 Principles of IT Governance}

This is supported by the definition of IT governance. Several definitions exist to define IT governance. Some of the more widely-used definitions are given here. According to IT Governance Institute/ITGI (2003), IT governance is defined as the responsibility of the board of directors and executive management. It is an essensial element of enterprise governance and include he leadership and organizational structures and processes that guaranty hat the organization's IT sustains and extends the organization's strategy and objectives. Based on Gartner (2006), IT governance is defined 
Proceeding ICOGISS 2019

Page 258-266. ISBN: 978-602-6 988-75-1

Web Jurnal Online: jurnal.unmuhjember.ac.id

By: Wheny Kristianto

Investigating It Governance Validity In Higher Education Institution: An Empirical Study

as the processes which ensure the effective and efficient use of IT in enabling an organisation to achieve its goals. Wijsman et al. (2007) give definition about IT governance as the joint responsibility of the executive management level of an organization and its supervisor(s) for (1) strategic planning and (2) internal control of the organization's deployment of IT and for (3) external accountability and (4) external supervision of the organization's deployment of IT.

\subsection{IT governance-Balanced Scorecard}

BSC can be refered on IT as initially described by Van Grembergen et al., (1997). The adaptations made by these authors generated a common scorecard for IT known in the literature as IT BSC. The success of the BSC in IT is due to its flexible design and comprehensive nature. By adding or altering individual measures and perspectives, the BSC can be tailored to suit the strategy of any organization (Erek, 2011). Moreover, a cascade of BSC can be used across multiple organizational levels supporting strategic alignment (Van Grembergen et al., 2003). Because of its easy adaptability, many issues have been addressed by using the IT BSC framework, such as, evaluating IT projects (Aubert et al., 2010), evaluate IT departments performance (Lee at al.,, 2008), evaluating IS performance (Rosemann, 2001), prevent sub-optimization of IT performance (Amado et al., 2012), ensuring strategic alignment between IT and the business (Van Grembergen \& Saull, 2001), integration of business and IT governance (Borousan et al., 2011), and others.

\subsection{Importance Performance Analysis}

Martilla and James (1977) introduced IPA, is a method which has been broadly used in marketing research, especially for developing and improving strategy. IPA, on the other hand, is a heavy evaluation instrument for practitioners and academics to find out attributes that are doing well and attributes that need to be improved, which require actions immediately (Liu \& Picolli, 2007). In short, Konsynski \& Tiwana (2004) argued that IPA evaluation equipment is used to prescribe the prioritisation of attributes for improvement and it can also provide guidance for strategic development. The explanation of the original IPA is described as follow: (a) Quadrant I (High Importance/Low Performance) is labelled Concentrate Here. Attributes that fall into this quadrant represent key areas that need to be improved with top priority; (b) Quadrant II (High Importance/High Performance) is labelled Keep up the good work. All attributes that fall into this quadrant are the strength and pillar of the organisations, and they should be the pride of the organisations; (c) Quadrant III (Low Importance/Low Performance) is labelled Low Priority. Thus, any of the attributes that fall into this quadrant are not important and pose no threat to the organisations; and (d) Quadrant IV (Low Importance/High Performance) is labelled as Possible Overkill. It denotes attributes that are overly emphasized by the organisations; therefore, organisations should reflect on these attributes, instead of continuing to focus in this quadrant, they should allocate more resources to deal with attributes that reside in quadrant I. 
Proceeding ICOGISS 2019

Page 258-266. ISBN: 978-602-6 988-75-1

Web Jurnal Online: jurnal.unmuhjember.ac.id

By: Wheny Kristianto

Investigating It Governance Validity In Higher Education Institution: An Empirical Study

\section{Research Method}

This research used a quantitative survey to identify the current state of IT governance for higher education organizations in East Java, Indonesia. A self-assessment was developed based on the metrics from IT governance BSC introduced by Abu-Musa (2007). The questionnaire consists of 23 items within four dimensions, as shown in Figure 3. According to these metrics (Abu-Musa, 2007), we used three-point Likert scale to measure the importance ( $1 \frac{1 / 4}{4}$ not important to $3 \frac{1}{4}$ very important) and performance (1 $1 / 4$ not monitoring to $31 / 4$ always monitoring). The questionnaires were distributed to postgraduate student as IT executives in their higher education institutions.

Sampel data were collected by administering the survey instrument to five higher education institutions on East Java. The survey instrument was handed out to the academic staffs who have experience in some strategic position in their institution as IT executive. They were asked to capture the perceived importance and performance for each attribute. A total of 34 out of 40 academic staffs completed the questionnaire, representing a response rate of 85 percent. The reliability analysis was carried out by calculating the Cronbach's $\alpha$ coefficient. The result showed a high internal consistency as shown in Table 1. After reliability testing was performed, a paired-sample $t$-test was run to evaluate the mean difference between performance and importance scores. IPA was then applied to capture graphical demonstration for identifying the current stage of IT governance and also providing the strategic actions for the higher education institutions.

Table 1. Cronbach's $\alpha$ and reliability of scale

\begin{tabular}{|l|l|l|l|}
\hline Constructs & Items & $\begin{array}{l}\text { Cronbach's } \alpha \\
\text { (importance) }\end{array}$ & $\begin{array}{l}\text { Cronbach's } \alpha \\
\text { (performance) }\end{array}$ \\
\hline $\begin{array}{l}\text { Corporate } \\
\text { contribution }\end{array}$ & $\begin{array}{l}\text { Five items (V1, V2, V3, V4 and } \\
\text { V5) }\end{array}$ & 0.441 & 0.460 \\
\hline $\begin{array}{l}\text { Future } \\
\text { orientation }\end{array}$ & $\begin{array}{l}\text { Five items (V6, V7, V8, V9 and } \\
\text { V10) }\end{array}$ & 0.415 & 0.515 \\
\hline $\begin{array}{l}\text { Stakeholder } \\
\text { orientation }\end{array}$ & $\begin{array}{l}\text { Four items (V11, V12, V13 and } \\
\text { V14) }\end{array}$ & 0.333 & 0.377 \\
\hline $\begin{array}{l}\text { Operational } \\
\text { excellence }\end{array}$ & $\begin{array}{l}\text { Nine items (V15, V16, V17, } \\
\text { V18,V19, V20, V21, V22 and } \\
\text { V23) }\end{array}$ & 0.469 & 0.401 \\
\hline & All items & 0.415 & 0.439 \\
\hline
\end{tabular}

\section{Research Result}

This section presents key results related to academic staff' perceptions as IT executive' perceptions of the importance of IT governance performance measures performed at their higher education insitutions. The graphical parable of the IPA is shown in Figure 3. In addition, the implications of the results obtained are also discussed in this section. The important performance matrix of IT governance-BSC attribute is plotted in four quadrants, as shown in Figure 2. Important values are presented on the vertical axis, while performance values are presented on the horizontal axis. 
Page 258-266. ISBN: 978-602-6 988-75-1

Web Jurnal Online: jurnal.unmuhjember.ac.id

By: Wheny Kristianto

Investigating It Governance Validity In Higher Education Institution: An Empirical Study

\subsection{The concentrate here quadrant}

The IT executive identifies 19 attributes in the squares here, which can be considered as adequate controls for attributes that need to be noticed. This is due to the fact that the attributes for IT governance BSC can perform not only as performance measurements, but former attribute groups can also influence the next group / perspectives, as shown in Figure 2. The lack of auditing in source attributes can affect the control of destination attributes. Therefore, all attributes in the quadrant concentrate here must be reconsidered for results and consequences.

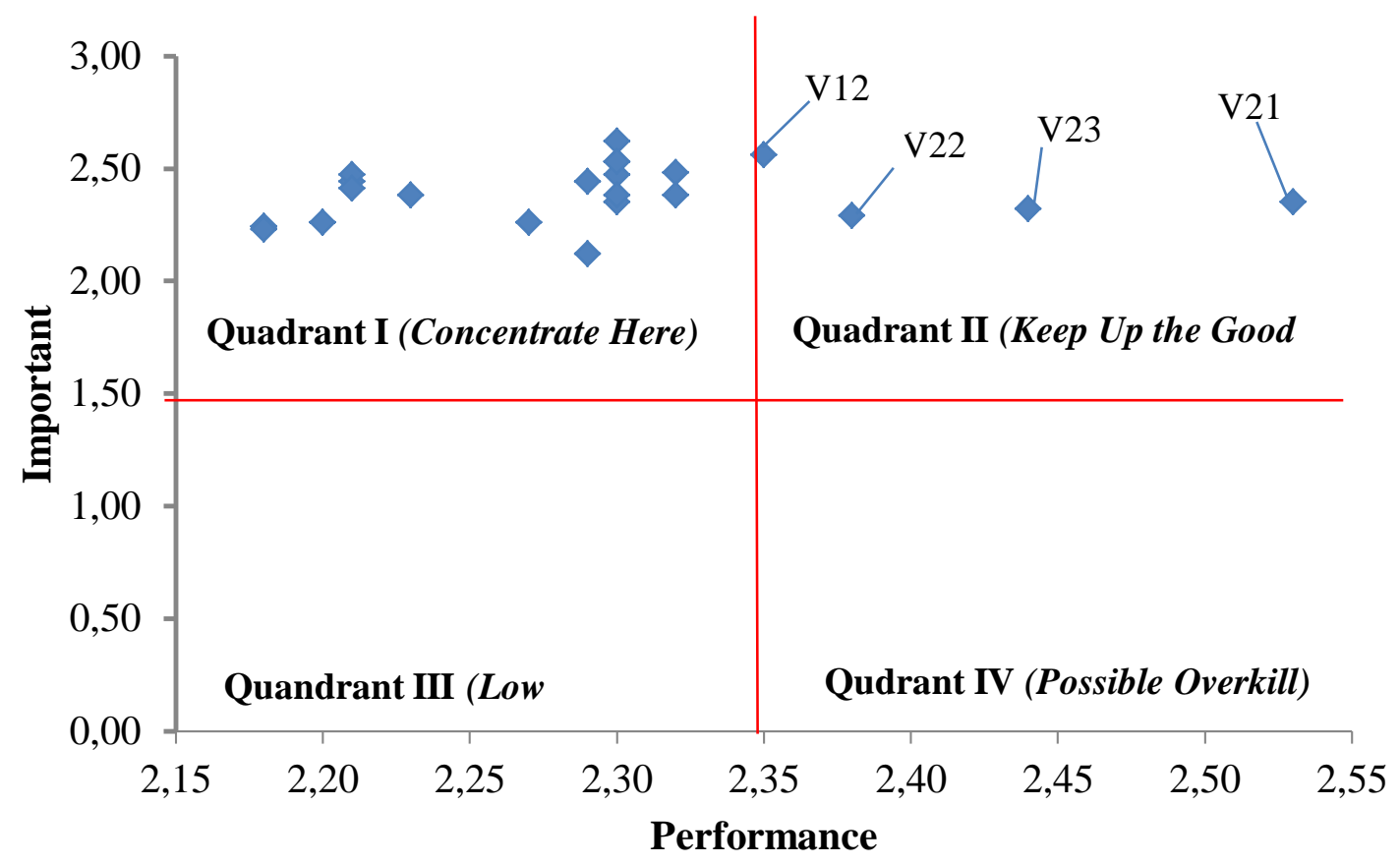

Figure 2. Plotting of importance-performance matrix for IT governance BSC attributes

\subsection{The keep up the good work quadrant}

According to the IT executive perception, 4 attributes (V12, V21, V22, and V23) have been identified in the keep up the good work quadrant. The important attributes that fall into quadrant II can be measured in a consistent way. These attributes are expected to be the pillar of strength for leading IT governance in the higher education institutions. Therefore, all attributes in the keep up the good work quadrant can be used as the baseline indicators for driving IT governance in five higher education institutions in East Java.

\subsection{The low priority quadrant}

In quadrant III, there is no attribute that fall into the low priority quadrant. This means that all IT executives perceived the performance measurement of IT governance in their higher education institutions can be conducted well. There is no important attributes that perform a low level monitoring. Even if we found evidence for lower expected 
Page 258-266. ISBN: 978-602-6 988-75-1

Web Jurnal Online: jurnal.unmuhjember.ac.id

By: Wheny Kristianto

Investigating It Governance Validity In Higher Education Institution: An Empirical Study

control with 14 attributes in Table 2, it would not be considered as a critical point when comparing with the result reflected in this quadrant.

\subsection{The possible overkill quadrant}

There is no attribute falls into the possibility of an excessive quadrant. If there are attributes that reside in this quadrant, those attributes are considered to be doing a lot of control. Therefore, if the attribute is the IT executive must reconsider the importance of this attribute. If the last discussion identifies the same utterance, then it can reduce the effort for this attribute.

\section{Discussion}

This study applies IPA analysis with IT governance BSC to capture the perceptions of IT executives represented by academic staffs regarding the importance of IT governance performance measures performed at their higher education institutions. When applying IPA to strategic equipments such as IT governance BSC, the results obtained must be interpreted with caution in order not to provide false information. Because the metrics of IT governance BSC are shown in the form of cause and effect, the results obtained must be reshaped from the original IPA analysis.

From the results of IPA analysis obtained data that there are many attributes in quadrant I and some attributes are in quadrant II . This can be a consideration for IT executives to pay attention to both quadrants. If there are attributes fall into quadrants III and IV it does not mean these attributes are unnecessary, but this can be information for IT executives to consider more thoroughly and give priority to attributes that have more impact and have consequences on higher education institutions performance. If they confirm that an existing metric is not important, unnecessary metrics must be rejected. After recovering unnecessary Indicators, IT executives can follow up on three strategic actions to elevate their ability to set IT at their higher education, as shown in Figure 3.

There are three strategies that can be used as guidance in the analysis using IPA. Strategy 1 (S1) is intended to support the attributes that fall into unimportant region to rise up to important region. Strategy 2 (S2) aims to rise up the attributes that fall into low performance region to high performance region. Strategy 3 (S3) is intended to rise up both attributes that fall into low performance and unimportant region to high performance and important region. 


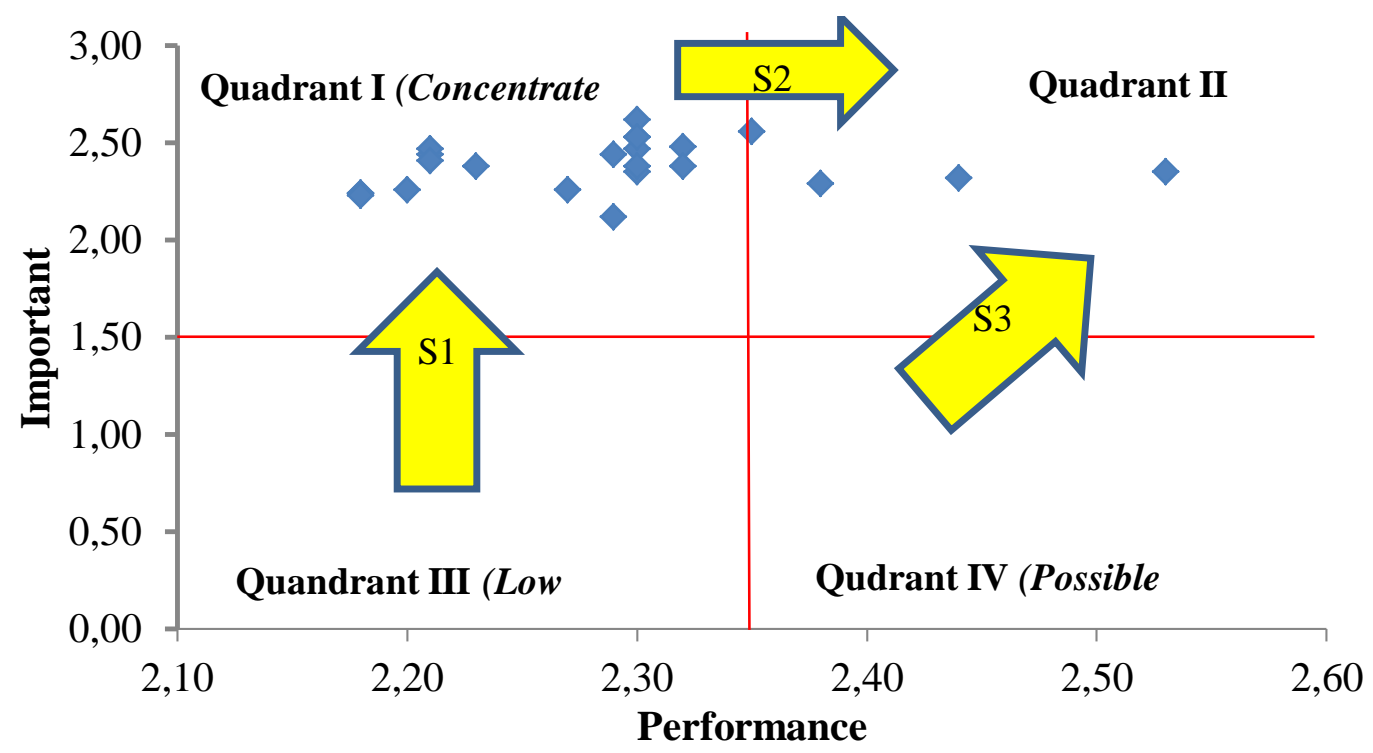

Figure 3. IT governance strategic guidance for higher educatin institution in East Java based on IPA

Based on the results of the analysis, the recommended strategy to use is Strategy 2 which aims to increase attributes that fall into low performing regions to high performing regions. According to Strategy 2, IT executives should focus on identifying indicators that should be consistent with their internal IT processes. All attributes in the quadrant concentrate here must be reconsidered for results and consequences. Furthermore, all stakeholders should be involved in the development of these indicators to gain wider acceptance.

\section{Conclusion}

There are two conclusions from this study to answer the research objectives. First, IT executives can implement BSC IT governance metrics with IPA to clarify the current situation of IT governance performance at their heigher education. Consequently, the strategic actions of IT governance for five higher education institutions in East Java could take place. In addition, the control framework currently used in higher education institutions may be tailored to the implications of the IPA.

Second, based on the IPA results, five higher education institutions in East Java can apply 4 attributes that are included in keep up the good work as an early indicator to drive IT governance at their higher education institutions. In the long run, IT executives can apply the IT governance strategic recommendations provided by this study using S2 as a guide to focus on attributes included in the concentrate here to be pushed toward keep up the good work. In further study, an insight review of articles based on a global IT governance perspective and practical guidance from a regional survey can be combined to draw a flexible IT governance framework for five higher education instiutions in East Java. 
Proceeding ICOGISS 2019

Page 258-266. ISBN: 978-602-6 988-75-1

Web Jurnal Online: jurnal.unmuhjember.ac.id

By: Wheny Kristianto

Investigating It Governance Validity In Higher Education Institution: An Empirical Study

\section{References}

Abu-Musa, A.A. 2007. Exploring Information Technology Governance (ITG) in Developing Countries: An Empirical Study. The International Journal of Digital Accounting Research, Vol. 7, N. 13-14, 2007, pp. 73-118.

Amado, C. A., Santos, S. P., and Marques, P. M. 2012. Integrating the Data Envelopment Analysis and the Balanced Scorecard approaches for enhanced performance assessment. Omega, Vol. 40, No. 3, pp. 390-403.

Aubert, B., Cohendet, P., Da Silva, L., Grandadam, D., Guimaron, J., and Montreuil, B. (2010). L'innovation et les technologies de l'Information et des communications. Centre sur la productivité et la prospérité (HEC Montréal), \& CEFRIO.

Borousan, E., Hojabri.R., Manafi, M., and Hooman, A. 2011. Balanced Scorecard; a Equipment for Measuring and Modifying IT Governance in Healthcare Organizations. International Journal of Innovation, Management and Technology, Vol. 2, No. 2, pp. 141-146.

Brown, R., 2008. Higher education and the market. Perspectives: Policy Practice Higher Educ. Vol. 12, pp. 78-83.

Erek, K. 2011. From green IT to sustainable information systems management: Managing and measuring sustainability in IT organizations. In Proceedings of the European, Mediterranean \& Middle Eastern Conference on Information Systems, pp. 1-16.

Gaspar, D. and Mabic, M. 2015. Creativity in higher education. Universal J. Educ. Res. Vol. 3, No. 9, pp. 598-605.

Gartner. 2006. Defining IT governance: Roles and relationships ITGI (IT Governance Institute). Board briefing on IT governance.

Gibbs, P., and Barnett, R., 2014. Thinking about higher education. Thinking About Higher Education.

Haerani, R. 2017. Mengukur Tingkat Kinerja Tata Kelola Teknologi Informasi di Perguruan Tinggi Menggunakan IT Balanced Scorecard. Jurnal Sistem Informasi, Vol. 4, hal. 25-28.

Hoidn, S., and Kärkkäinen, K., 2014. Promoting Skills for Innovation in Higher Education. OECD Education Working Papers, (100), 0_1,1,5-61.

ITGI. 2003. Board Briefing on IT Governance. IT Governance Insitute.

Konsynski, B., and Tiwana, A. 2004. The improvisation efficiency paradox in inter-firm electronic networks: governance and architecture considerations. Journal of Information Technology, 1Vol. 9, No.4, pp. 234-243.

Liu, T. W., and Piccoli, G. 2007. Degrees of agility: implications for information systems design and firm strategy. Agile information systems: Conceptualization, construction, and management, pp. 122-133

Mathew, V., 2010. Service delivery through knowledge management in higher education. Journal of Knowledge Management Practice 11, 1-16.

Martilla, J.A. and James, J.C. 1977. Importance-performance analysis. Journal of Marketing, Vol. 41 No. 1, pp. 77-79. 
Proceeding ICOGISS 2019

Page 258-266. ISBN: 978-602-6 988-75-1

Web Jurnal Online: jurnal.unmuhjember.ac.id

By: Wheny Kristianto

Investigating It Governance Validity In Higher Education Institution: An Empirical Study

Meek, L., Teichler, U., and Kearney, M., 2009. Higher Education, Research and Innovation: Changing Dynamics. Report on the UNESCO Forum on Higher Education, Research and Knowledge. International Centre for Higher Education Research.

Misbah, Hadi, S.P., dan Nugroho, E. 2017. Penerapan Information Technology Balanced scorecard (IT BSC) Pada Perancangan Tata Kelola Teknologi Informasi Menggunakan Kerangka Kerja COBIT 5. Seminar Nasional Sains dan Teknologi, Jakarta, hal. 1-7, Jakarta.

OECD, 2009. Higher Education to 2030. Higher Education, Vol. 2.

Prabowo, H. 2007. Implementasi IT Balanced Scorecard di Perguruan Tinggi. Seminar Nasional Aplikasi Teknologi Informasi 2007 (SNATI 2007), J-59-J-62, Yogyakarta.

Rosemann, M. 2001. Evaluating the management of enterprise systems with the Balanced Scorecard. Information Technology Evaluation Methods and Management, pp. 171-184.

Solechan, A. 2015. Tata Kelola Kinerja Teknologi Informasi Menggunakan IT Balanced Scorecard (Studi Pada STMIK Provinsi Semarang). Jurnal Teknologi Informasi dan Komunikasi, Vol. 6, No. 2, hal.61-66.

Van Grembergen, W. and Van Bruggen, R. 1997. Measuring and improving corporate information technology through the balanced scorecard technique. In Proceedings of the Fourth European Conference on the Evaluation of Information technology, pp. 163-171).

Van Grembergen, W., Saull, R., and De Haes, S. 2003. Linking the IT balanced scorecard to the business objectives at a major Canadian financial group. Journal of Information Technology Case and Application Research, Vol. 5, No. 1, pp. 2350 .

Van Grembergen, W. and Saull, R. 2001. Aligning business and information technology through the balanced scorecard at a major Canadian financial group: its status measured with an IT BSC maturity model. Proceedings of the 34th Annual Hawaii International Conference on System Science, IEEE, pp. 1-10.

Wijsman, T., Neelissen, P. and Wauters, C. 2007. IT governance in the public sector: 'Top-priority'. The INTOSAI IT Journal, 25:20-29.

Zhu, C., 2015. Organisational culture and technology-enhanced innovation in higher education. Technol. Pedagogy Educ. Vol. 24, No.1, pp. 65-79. 